\title{
Students' Subject-Verb Agreement Errors in Paragraph Writing Class
}

\author{
Yustinus Calvin Gai Mali \\ Made Frida Yulia
}

\begin{abstract}
Subject-verb agreement is an essential element to master by English Language Education Study Program (ELESP) students, who are prepared to be English teachers in the future. However, the researchers still find the fact that ELESP students make the errors on the agreement. For that reason, it would be significant to find out the errors made by the students as well as to discover the factors behind the errors. To achieve those purposes, the researchers conducted a document analysis and a semi-structure interview.The research results showed most of the errors belonged to misinformation category (71.4\%) and were subsequently followed by omission category (17.9\%) and addition category (10.7\%). In addition, from the interview, the researchers also found five (5) major factors that caused the students to make the errors, namely interlingual error, ignorance of rule restrictions, incomplete application of rules, false concepts hypothesized, and carelessness.
\end{abstract}

Keywords: errors, subject-verb agreement, Paragraph Writing Class

\section{A. INTRODUCTION}

The English Language Education Study Program of Sanata Dharma University Yogyakarta, henceforth called ELESP, aims to prepare its students to become both an English language user in professional fields and a future English teacher. As teachers' candidates who are going to be a model for their future students, ELESP students are required to learn English skills. Besides, they should be able to master the skills before they are ready to teach them and be a model for their future students.

Essentially, one of the skills that they learn is English writing. In writing an English sentence, they are required to think about and subsequently write a correct subject and a verb within the sentence. This may possibly indicate that subject-verb agreement becomes one of the essential aspects to learn since it is required by the students to make a grammatically correct sentence. ELESP students, therefore,need to learn and to master the agreement between subject and verb. It makesthemable to apply the correct agreement in a sentence and subsequently to teach their future students of a sentence whose subject-verb agreement is correct.

Nevertheless, in a learning process, learners who study English writing make errors. Dulay, Burt, and Krashen (1982) mention that teachers who have experienced long concerning their students' language errors have come to realize that making errors become an inevitable part of learning. Interestingly, errors are important in a process of learning and they may actually become an essential part in learning a language (Norrish, 1983).

Considering the importance of learning, understanding and mastering agreement between a subject and a verb in a sentence and the fact that learners make errors in the process of learning, the researchersare interested to study subjectverb agreement errors made by students in Paragraph Writing class at ELESP. More specifically, the researchers aim to solve 
two research problems. Firstly,what are subject-verb agreement errors that are made by students in Paragraph Writing class of ELESP?Secondly, what are the factors that cause students in Paragraph Writing class of ELESP to make those subject-verb agreement errors?

\section{B. LITERARY REVIEW \\ a. Subject-Verb Agreement}

Some theorists propose their ideas on the concept of subject and verb agreement. According to Wood (1981), the rule of subjectverb agreement states that a verb must agree with its subject in number and in person. Essentially, the subject may determine the concord (Quirk \& Greenbaum, 1973). Leech and Svartvik (1994) clarify that grammatical concord indicates that certain grammatical items agree with each other. Thus, we may consider concord as an agreement. Leech and Svartvik (1994) further mention that there are two types of concord, namely concord of number, for instance, as in singular: the film is and as in plural: the films are and concord of person, for example, as in 1st person: I am and as in 2nd person: you are.

Further concepts of the subjectverb agreement are clarified. Quirk and Greenbaum (1973) state that "the selected form of a verb, which permits a distinction between singular and plural, depends on whether the subject is singular as in the man makes, or plural as in the men make"(p. 11). Greenbaum (1989) adds that the agreement of subject and verb is always applied whenever the verb displays distinctions in number and in person. Greenbaum (1989) further mentions that "for all verbs other than be, the distinctions only happen in Present Tense, where the third person singular has the $-s$ form and the third person plural, which is like the first and the second persons, has the base form" (p. 208).

\section{b. Errors: The Types and the Sources}

It is essential to classify errors based on the types because various errors may be found in learners' writing production. The purpose is to make the researchers able to analyze the errors found in learners' writing production easier.

Based on Surface Structure Taxonomy, errors can be categorized into four types, namely omission, addition, misinformation, and misordering (Dulay (1982) as cited in Ellis \& Barkhuizen, 2005).

Researchers and linguists have thought about possible causes of errors made by language learners. According to Ellis and Barkhuizen (2005), in order to be able to explain errors, people essentially need to ask what processes learners invoke when they do not understand the targetlanguage form.In addition, they mention that traditionally, there are two major processes are identified: distinguishing interlingual errorsand intralingual errors. Besides interlanguage errors and intralingual errors, there are other possible causes of errors made by learners. Those are carelessness, translation and error as a part of language creativity (Norrish, 1983) and context of learning (Brown, 1980).

\section{METHODOLOGY}

\section{a. Participants}

Thirty students in class B of Paragraph Writing at ELESP in 2010/ 2011 academic year were chosen as the participants of the research. It was due to the assumption that they were likely to make errors because as freshmen, they had limited knowledge in producing English sentences. They were only equipped with the theory of writing from Basic Writing class in semester one. Furthermore, the selection of the participants was also based on the accessibility to the participants, time, and financial reason. 


\section{b. Method}

The researchers employed a document analysis and a semi-structured interview. The documents were the students' written work of their Progress Test II. The students were asked to write a descriptive text, which required students to use Present Tense in writing the text. This implied that there would be a lot of occurrences of subjectverb agreement in number and in person. Then, in order to obtain more information from the participants, the researchers employed semi-structured interview to eight (8) students who made various subject-verb agreement errors in their written work in the selected Paragraph Writing class.

\section{FINDINGS AND DISCUSSION}

\section{a. The Students' Subject-Verb Agreement Errors}

From thirty (30) students' written work, twenty-eight (28) subject-verb agreement errors were found. The occurrence of the errors in all students' written work varied. Table 1 presents detailed information about the types of errors, number of occurrences, and the sample context in which the errors occurred. From the table, it was obvious that the types of subject-verb agreement errors that the researchers found in the students' written work cover four different categories of errors. They are (1) omission, (2) doublemarking, which is under addition category (3) simple addition, which is another subcategory of addition category, (4) archi forms/alternating forms, which are under the misinformation categories.

There were five (5) errors or $17.9 \%$ of the total errors that were classified as omission errors. According to Dulay et al. (1982), omission errors refer to the absence of an item that actually must exist in a wellformed utterance (p. 154).

Table 1. The Number of Subject-Verb Agreement Errors Made by the Students

\begin{tabular}{|c|c|c|c|c|}
\hline No & $\begin{array}{l}\text { Category } \\
\text { of Errors }\end{array}$ & $\begin{array}{l}\text { Sub Category } \\
\text { of Errors }\end{array}$ & $\begin{array}{l}\text { Number } \\
\text { of Errors and } \\
\text { Its Percentage }\end{array}$ & Samples of Errors \\
\hline \multirow[b]{2}{*}{1.} & \multirow[b]{2}{*}{ Omission } & \multirow[b]{2}{*}{ - } & \multirow{2}{*}{$\begin{array}{l}5 \\
(17.9 \%)\end{array}$} & $\begin{array}{l}\text { The fragrance of the flower comfort everybody who } \\
\text { comes to my house. (singular marker }-\mathrm{s} \text { for the verb } \\
{ }^{*} \text { comfort) }\end{array}$ \\
\hline & & & & $\begin{array}{l}\text { The garden has a lot of kinds of flowers, so it make } \\
\text { my garden colorful and more beautiful to see. } \\
\text { (singular marker -s for the verb }{ }^{*} \text { make) }\end{array}$ \\
\hline \multirow[b]{3}{*}{2.} & \multirow[b]{3}{*}{ Addition } & Regularization & $\begin{array}{l}0 \\
(0 \%)\end{array}$ & - \\
\hline & & $\begin{array}{l}\text { Double } \\
\text { Marking }\end{array}$ & $\begin{array}{l}1 \\
(3.6 \%)\end{array}$ & $\begin{array}{l}\text { It is located in an area which doesn't has much } \\
\text { pollutant, so the air is still fresh.(the negative marker } \\
\text { for singular verb doesn't *has) }\end{array}$ \\
\hline & & $\begin{array}{l}\text { Simple } \\
\text { Addition }\end{array}$ & $\begin{array}{l}2 \\
(7.1 \%)\end{array}$ & $\begin{array}{l}\text { The living room has a window, when we open the } \\
\text { window in the morning, the ray of the sun will shining } \\
\text { brightly through the window and touch our skin. } \\
\text { ("-ing" formin the verb *shining, whose position is } \\
\text { after the modal auxiliary, will) }\end{array}$ \\
\hline
\end{tabular}




\begin{tabular}{|l|l|l|l|l|}
\hline & & Regularization & $0(0 \%)$ & - \\
\cline { 3 - 5 } & & & & $\begin{array}{l}\text { Each of the rooms also have to has some furnitures } \\
\text { which is needed. } \\
\text { (Incorrect use of the verb *have for the subject each } \\
\text { of the rooms, whose form is singular) }\end{array}$ \\
\hline information & $\begin{array}{l}\text { Archi Forms/ } \\
\text { Alternating } \\
\text { Forms }\end{array}$ & $\begin{array}{l}20 \\
(71.4 \%)\end{array}$ & $\begin{array}{l}\text { The bedrooms has a beautiful view from the } \\
\text { backyard. } \\
\text { (Inccorect form of the verb *has for the subject the } \\
\text { bedrooms, whose form is plural) }\end{array}$ \\
\hline 4. & Misordering & - & $0(0 \%)$ & - \\
\hline
\end{tabular}

This is one of the examples of omission errors category.

*The fragrance of the flower comfort everybody who comes to my house.

In sentence [1a], the omission error occurred in the verb ${ }^{*}$ comfort because the student did not apply the singular marker $-s$ in the verb * comfort in order to indicate that the verb has singular meaning. In sentence [1a], the subject, the fragrance of the flower, is considered singular because the head subject, the fragrance, is considered an uncountable noun, which belongs to gases category (Azar, 1989, p. 206). According to Langan (1996), words that come between the subject and the verb in a sentence do not change the subject-verb agreement within the sentence. Moreover, since the word, thefragrance,belongs to uncountable noun, it has singular meaning. Greenbaum (1989) states that non-count nouns are considered singular.

Thus, in order to form a correct subject-verb agreement in sentence [1a], the student should apply the singular marker $-s$, for the verb, ${ }^{*}$ comfort. It aimed to indicate that the verb has singular meaning, so the subject-verb agreement in number in sentence [1a] could be formed. Therefore, the correction of sentence [1a] is:

[1b] The fragrance of the flower comforts everybody who comes to my house.
After analyzing the students' written work, the researchers only found one (1) error or $3.6 \%$ of the total errors regarded as double-marking error, which is the subcategory of addition error. According to Dulay et al. (1982), an error is classified into double-marking category when a student uses two items rather one, which are marked for the same feature. The error of this type could be seen in sentence [2a].

[1a] *It is located in an area which doesn't has much pollutant, so the air is still fresh.

Sentence [2a] is a deviant form of sentence:

[2b] It is located in an area which doesn't have much pollutant, so the air is still fresh.

In sentence [2a] the double-marking error occurred in the negative form *doesn't has of the subject, an area. In sentence [2a], the student used the same features, which are all singular form, to indicate the negative meaning: doesn't and has. The student should have used a plural form, have, after the word doesn't, so the subject-verb agreement in number could be made.

Besides, the researchers also found two (2) errors or $7.1 \%$ of the total errors on simple addition, which is still another subcategory of addition error category. According to Ellis and Barkhuizen (2005), an error can be classified under simple addition category when the addition error does not 
involve regularization, which can happen because "a marker is erroneously added to exceptional items of the given class that does not take a marker" (Dulay et al., 1982, p. 156) and double-marking error, which can happen because of two items marked for the same feature (Dulay et al., 1982). Thus, the learner might make some simple addition errors because they simply added a feature that actually should not be put in a sentence. The researchers provide an example of simple addition error found in the students' written work.

[2a] *The living room has a window, when we open the window in the morning, the ray of the sun will shining brightly through the window and touch our skin.

The simple addition error in sentence [4a] occurred in the word *shining, whose position after the modal auxiliary, will (Leech \& Svartvik, 1994, p. 244). Leech and Svartvik (1994) state that modal auxiliaries only have one form and do not have such forms as $-s$ forms, -ing forms, or -ed participles. Further, Azar and Hagen (2006) mention that modal auxiliaries come in front of the simple form of a main verb. Accordingly, sentence [3a] should be:

[3b] The living room has a window, when we open the window in the morning, the ray of the sun will shine brightly through the window and touch our skin.

Under misinformation category, which may happen because of the use of an incorrect form of a morpheme or structure (Ellis \& Barkhuizen, 2005), the researchers did not find any errors on regularization. Nevertheless, the researchers found many subject-verb agreement errors that belonged to another subcategory of misinformation, namely archi/alternating forms. There were twenty (20) archi/alternating forms errors or $71.4 \%$ of the total errors. Sentence [4a] becomes an example of these archi/ alternating forms.

[3a] *The bedrooms has a beautiful view from the backyard.

The error in sentence [4a] might happen because the student used the singular verb, has, which should not follow the plural subject of sentence [4a], the bedrooms. The subject-verb agreement in number of sentence [4a] could be formed only if the student had applied the plural verb, have, in order to follow the plural subject. Therefore, sentence [4b]; the bedrooms have a beautiful view from the backyard, becomes the correction of sentence [4a].

\section{b. The Factors that Caused the Students to Make the Errors}

From the interview, the researchers could find five (5) major factors that caused students to make subject-verb agreement errors. Those factors were interlingual error, ignorance of rule restrictions, incomplete application of rules, false concepts hypothesized, and carelessness.

\section{i. Interlingual Error}

According to Ellis and Barkhuizen (2005), interlingual errors are the result of mother tongue influences (p. 65).In the interview, most of the respondents admitted that the errors on subject-verb agreement could happen because they were still influenced by their mother tongue, which is Indonesian language. Some respondents stated that they have been accustomed to Indonesian sentences, which does not require them to apply the complicated rules as what they have to apply in writing English sentences.

In addition, when the respondents wrote an Indonesian sentence, they did not need to think about whether the subject was singular or plural, whether to use simple 
form or simple pastform or past participle form of a verb. Therefore, when they had to write an English sentence, they might forget to apply the required rules in a sentence that they wrote, especially the rules of subjectverb agreement, even they might still apply the same concepts as those they used in writing Indonesian sentences when they write an English sentence. It was because the concepts of Indonesian language had already influenced them and stayed in their mind when they wrote an English sentence. Consequently, they might forget to consider the subject-verb agreement when they wrote an English sentence. Therefore, that condition would automatically cause them to make errors on the subject-verb agreement.

\section{ii. Ignorance of Rule Restrictions}

According to Richards (1974), "ignorance of rule restrictions is the application of rules to contexts where they do not apply" (p. 175). In addition, Richards (1974) adds that analogy, the learners rationalizing a deviant usage from his previous experience of English, may cause them to make some rule restriction errors. Most of the respondents claimed that they sometimes were still confused about the usage of one rule compared to other rules, which were required to be implemented in writing an English sentence. Moreover, it was also admitted that while writing English sentence, they still implemented the incorrect rules for subject-verb agreement. It was because when they wrote a sentence, they analogized certain grammatical rule of English language then considered it the same as that of subject-verb agreement. Then, they applied that rule resulting from their analogy to write a sentence. They should have applied the rule of subject-verb agreement in that sentence not the other rules, resulting from their analogy.

\section{iii. Incomplete Application of Rules}

Richards (1971b) mentions that incomplete application of rules involves a failure to fully develop a structure (as cited in Ellis, 1994, p. 59). In addition, incomplete application of rules may also be caused by a failure to learn more complex types of structure. According to Richards (1974), this happens because the learner thinks that he can achieve effective communication by using relatively simple rules (as cited in Ellis, 1985, p. 53).

After analyzing the information obtained from the interview, the researchers found that before facing their Progress Test II, most of the respondents decided not to reread or to restudy the basic theories of writing, involving the theory of subject verb agreement, which might be needed to face their Progress Test II. It was because they thought that they had already understood and mastered the theory of subject-verb agreement, which they believed as basic and simple concept.

In addition, there were many essential rules of subject-verb agreement that should be mastered by respondents because the rules were not actually as simple as they thought. They still needed to restudy the rules of subject-verb agreement thoroughly before they wrote an English sentence and faced their Progress Test II. It aimed to minimize them to make subject-verb agreement errors when they wrote an English sentence.

From the information obtained from the interview, it was obvious that most of the respondents thought that they confidently would be able to write an English sentence whose subject-verb agreement was correct without either rereading or restudying the rules of subject-verb. Whereas, most of them needed to apply the theories while writing English sentences. 


\section{iv. False Concepts Hypothesized}

According to Richards (1974), false concepts hypothesized can happen because of faulty comprehension of distinctions in the target language. In this study the respondents experienced these false concepts hypothesized in understanding the subject-verb agreement in a sentence. It happened especially when they had to consider whether something was countable or uncountable.

From the information obtained from the respondent, it could be seen that when the respondents wrote an English sentence, they still found it difficult to differentiate whether a noun was countable or uncountable. One of the reasons was that they were not able to memorize all of the nouns, which belong either to countable group or to uncountable group. Because of that difficulty, most of the respondents admitted that they often added $-s$ for the uncountable noun, and applied the plural verb to follow that uncountable noun added by $-s$. Consequently, it caused them to make errors on subject-verb agreement in the sentence they wrote. Therefore, the researchers could say that the case of this faulty of concepts hypothesized happened because of the difficulty in differentiating countable noun from uncountable noun.

Furthermore, the faulty concepts hypothesized could also happen because of the confusion to consider whether certain pronoun has singular meaning or plural meaning and whether a noun followed by the adjectives has singular meaning or plural meaning.

\section{v. Carelessness}

Most of the respondents conveyed that carelessness was another factor that caused them to make errors on subject-verb agreement. Carelessness can be caused by learners' lack of motivation, but it is not only learners' fault if they lose interest (Norrish,
1974). According to Norrish (1974), learning materials and the style of presentation that do not accord learners can be other factors that make them have lack of motivation (p. 21).

In this study, the carelessness dealt with motivation. Three essential bases could affect the motivation of students. They were the students themselves who are able either to increase or to decrease their motivation, the way the lecturer teaches his/her students, and the learning material given by the lecturer. This motivation really had big effect on the learning process, especially in their writing skill, that students did. If a student was not motivated to learn something, he or she might obtain negative result on his or her learning process, especially while they were writing English sentences.

Some respondents agreed that errors on subject-verb happened because they were lack of motivation when they were in the classroom. It was because their lecturer could not explain the learning material clearly to the students. Consequently, when the respondents wrote the sentences, they wrote them carelessly. Thus, the errors in subject-verb agreement could possibly appear in their sentences.

Most of the respondents conveyed that when they were not able to understand the explanation from their lecturer, they tended to write a sentence with the existing knowledge that they had already known. Consequently, they could possibly make some errors in their sentence. One of them was the error on subject-verb agreement.

In addition, the researchers found that the feedback really had an essential role to minimize the errors and to help students not to make many errors, especially on subject-verb agreement. It was also found that lack of feedback from the lecturer to the errors on subject-verb agreement that the respondent made might also cause the 
respondents to continue making the same errors as what they had done.

Besides the lack of feedback given by their lecturer to the errors they made, most of the respondents also conveyed that the lack of motivation which was caused by themselves might also cause them to make errors on subject-verb agreement.Most of the respondents argued that having many assignments, with short time to finish, become the factor that could decrease their motivation to finish their assignments very well. In addition, they thought that they could not finish doing the assignments well in that short time. Thus, they tended to finish doing them carelessly. In addition, most of the respondents also agreed that their unwillingness to recheck the sentences after they had finished writing them could become a factor behind the subject-verb agreement errors in their written work.

\section{E. CONCLUSIONS}

The research firmly stated that the students in the class still made a number of subject-verb agreement errors in their writing. Misinformation, omission and addition became the major category of errors frequently made by the students. Those errors were caused by five major factors, namely interlingual error, ignorance of rule restrictions, incomplete application of rules, false concepts hypothesized, and carelessness.

\section{REFERENCES}

Azar, B. S. (1989). Understanding and Using English Grammar (2 ${ }^{\text {nd }}$ ed.). New Jersey: Prentice Hall Regents.

Azar, B. S. and Hagen S. A. (2006). Basic English Grammar (3 ${ }^{\text {rd }}$ ed.). New York: Pearson Longman.
Dulay, H., Burt, M., and Krashen, S. (1982). Language Two. New York: Oxford University Press, Inc.

Ellis, R. (1985). Understanding Second Language Acquisition. New York: Oxford University Press.

Ellis, R. (1994). The Study of Second Language Acquisition. New York: Oxford University Press.

Ellis, R. and Barkhuizen, G. (2005). Analysing Learner Language. Oxford: Oxford University Press.

Fraenkel, J. R. and Wallen, N. E. (2009). How to Design and Evaluate Research in Education. New York: McGraw-Hill.

Gall, M. D., Gall, J. P., Borg, W. R. (2007). Educational Research An Introduction ( $8^{\text {th }}$ ed.). Boston: Pearson Education, Inc.

Greenbaum, S. (1989). A College Grammar of English. New York: Longman Inc.

Langan, J. (1996). College Writing Skills ( $4^{\text {th }}$ ed.).New York: The McGraw-Hill Companies, Inc.

Leech, G. and Svartvik, J. (1994). A Communicative Grammar of English. London: Longman Group Limited.

McDonough, J. and McDonough, S. (2004). Research Methods for English Language Teachers. London: Arnold.

Norrish, J. (1983). Language Learners and Their Errors. Hong Kong: The Macmillan Press Limited.

Ouirk, R. and Greenbaum, S. (1973). A University Grammar of English. Essex: Longman.

Richards, J. C. (1974). Error Analysis. London: Longman Group Limited.

Wood, F. T. (1981). Current English Usage. London: The Macmillan Press Limited. 